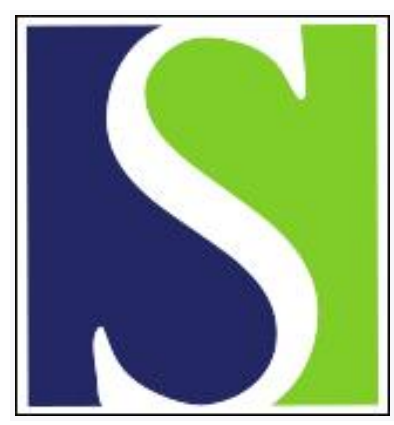

Scand J Work Environ Health 1997;23(2):83-92

https://doi.org/10.5271/sjweh.185

Issue date: Apr 1997

Surveillance and intervention studies on respiratory cancers in asbestos-exposed workers

by Merler E, Buiatti E, Vainio $\mathrm{H}$

Key terms: cancer risk; chemoprevention; medical surveillance; prospective study; respiratory cancer; smoking habit; trial

This article in PubMed: www.ncbi.nlm.nih.gov/pubmed/9167231

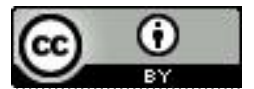




\title{
Surveillance and intervention studies on respiratory cancers in asbestos-exposed workers
}

\author{
by Enzo Merler, MD, ${ }^{1,2}$ Eva Buiatti, MD, ${ }^{2}$ Harri Vainio, MD, ${ }^{1,3}$
}

\begin{abstract}
Merler E, Buiatti E, Vainio $H$. Surveillance and intervention studies on respiratory cancers in asbestos-exposed workers. Scand J Work Environ Health 1997;23(2):83-92.

A systematic review of the literature on the surveillance of workers at presumed increased risk for respiratory cancer because of their exposure to asbestos revealed surveillance programs at the national, population, industrial, and factory (workplace) levels. Furthermore, 3 randomized chemoprevention trials involving workers exposed to asbestos were found. The nationwide programs to survey problems related to occupational exposure to asbestos were conducted in Europe. Some of the countries have policies for the surveillance of workers exposed either currently or formerly to asbestos. The results of the chemoprevention trials suggest that there are, as yet, no practical tools for efficient, safe chemoprevention of asbestos-induced respiratory malignancies.
\end{abstract}

Key terms cancer risks, chemoprevention, medical surveillance, prospective studies, respiratory cancers, smoking habits, trials.

Exposure to asbestos causes cancer and mesothelioma in human lungs in addition to asbestosis and pleural plaques and thickenings. Both nonsmokers and smokers exposed to asbestos fibers develop lung cancer, the risk being greatly increased in smokers (1). (For a review see reference 2.) A latency period of at least $10-20$ years between the first exposure to asbestos and the clinical manifestation of lung cancer is generally observed; the latency period is even longer for mesothelioma. Convincing evidence of the carcinogenic risk for asbestos exposure to humans resulted in risk management actions in several countries, varying from exposure limits to the banning of asbestos and asbestos-containing materials.

It is a long-standing occupational health practice to place asbestos workers under medical surveillance during employment, with the aim of detecting early signs of asbestos-related diseases. Such surveillance is usually undertaken as part of a broader set of actions, inclusive of surveillance exposure at the workplace and monitoring of individual members of the work force for the presence of effects that are not seen clinically. Medical surveillance is used for the purposes of compensation to verify the absence of asbestos-related diseases or to classify any that occur as a result of occupational exposure and to reduce individual exposure through changes in the workplace. Studies based on follow-up tend to be restricted to the period of employment, although the carcinogenic hazard represented by asbestos tends to accumulate despite reduction or cessation of current exposure (3).

Exposure to asbestos at work is usually some order of magnitude greater than that of the general population (4) so that workers are at high risk for cancer. Furthermore, because of their biopersistence and slow dissolution, asbestos fibers tend to accumulate in the lungs. Asbestosexposed workers are therefore often included in trials for evaluating the efficacy of cancer preventive strategies through early detection or primary prevention, with special reference to lung cancer.

Several screening techniques for lung cancer have been used on asbestos-exposed workers over the last 10 years, including repeated lung $\mathrm{X}$ rays, sputum cytology, or both. The difficulty of surgical excision of the lung tumors detected represents a limitation to such exercises, however, because of the concomitant impairment of respiratory capacity due to asbestosis. Furthermore, the effectiveness of screening for lung cancer with respect to an increase in survival or the avoidance of death from the disease has not been proved in controlled trials $(5,6)$.

1 International Agency for Research on Cancer, Lyon, France.

2 Centre for Study and Prevention of Cancer, USL 10, Florence, Italy.

3 Finnish Institute for Occupational Health, Helsinki, Finland.

Reprint requests to: Dr E Merler, Environmental Cancer Epidemiology Unit, IARC, 150 Cours Albert-Thomas, 69372 Lyon, Cedex 08, France. 
Studies of the effectiveness of chemoprevention (ie, chemical agents added to a person's usual regimen) in reducing the occurrence of respiratory cancers among asbestos workers have been undertaken recently, particularly on the possible preventive potential of beta-carotene.

The objective of this paper is to present a review of the published literature on surveillance and intervention studies, including chemoprevention trials, among workers at increased risk of developing respiratory cancer because of exposure to asbestos.

\section{Materials and methods}

The MEDLINE and CANCERLIT data bases for 1969 to 1996 were consulted to identify intervention studies, chemoprevention trials, smoking cessation programs, and medical surveillance programs for asbestos-exposed workers. As additional sources, we used the IARC directories of on-going research in cancer epidemiology (1977-1996) and some summary reviews on smoking cessation programs and their effectiveness $(7,8)$. No limitations were placed on the characteristics or quality of the studies when they were selected for this review.

\section{Results}

The available scientific literature can be divided into 3 main categories: surveillance programs in factories or industrial sectors, surveillance programs at the national or subnational level, and chemoprevention trials.

\section{Surveillance programs in factories or industrial sectors}

Studies of workers in factories and industrial sectors with potential exposure to asbestos are summarized in table 1 for those in which the method used for identifying the exposed is specified (9-18). Other methods have been proposed or tested to identify workers who have either been exposed to asbestos or have asbestos-related diseases, with the implicit aim of implementing a surveillance program thereafter. These include a method to identify cohorts with substantial exposure to asbestos in New Jersey (United States), as a first step in a program to notify individuals of their risks (19), a surveillance scheme of work-related occupational respiratory diseases (named SWORD) established in the United Kingdom through periodic contact with chest and occupational physicians, who provided data on new cases of parenchymal asbestosis and benign pleural disease (20), and the use of hospital discharge data to identify new cases of asbestosis (21). The last 2 studies resulted in the identification of a large number of affected subjects who would otherwise have gone undetected.

Most of the studies summarized in table 1 were conducted in the United States and involved workers in industries or factories. These programs, in general, share a lower participation rate than health education programs. Only 2 of the studies included a smoking cessation program based on counseling by a physician and an evaluation of the proportion of those who had not resumed smoking 1 or 2 years later. The smoking cessation program for shipyard workers at the naval shipyard in Charleston, South Carolina, in the United States (12) involved a comprehensive questionnaire on the workers' knowledge, attitudes, and beliefs about the adverse effects of smoking (11).

\section{Surveillance programs at the national or subnational level}

Large surveillance programs have been launched or are in progress in some European countries (table 2) (2235 ). Programs at these levels result in large numbers of workers and high participation rates.

The appropriateness of the new standard for asbestos introduced in the United Kingdom in 1969 was evaluated by examining the health of exposed subjects and evaluating their mortality prospectively after the new regulations had been applied $(22-24)$. Information on exposure in the factories was collected in parallel. The program required periodic medical examinations, including a standardized interview on exposure and smoking habits.

The German program $(25,26)$ was a result of pressure from insurance bodies on former and current asbestos-exposed workers to accept health examinations after leaving employment, with the aim of using the collected individual information for better compensation of asbestos-related diseases. It is worth noting that, in 1992, Germany decided to stop the trading of asbestos and asbestos-containing materials. In both the United Kingdom and Germany, data on smoking status were collected in order to evaluate whether smoking modifies the cancer risk related to exposure to asbestos.

The approaches used in Finland (27-29) and Norway $(30-35)$ were developed to identify subjects who had been exposed to asbestos in the past in order to persuade them to reduce their smoking habit. A law prohibiting the use of asbestos came into effect in both countries before the programs started. The surveillance program in Finland was carried out with other actions aimed at reducing the use of and exposure to asbestos, including a ban in 1990 on the manufacture, import, and use of asbestos-containing products. Through the use of various record systems efforts were made to identify and contact subjects who had had significant occupational 
Table 1. Surveillance programs in factories and industrial sectors with exposure to asbestos.

\begin{tabular}{|c|c|c|c|c|}
\hline \multirow[t]{2}{*}{ Reference } & \multirow{2}{*}{$\begin{array}{l}\text { Factory or industrial sector } \\
\text { reference(s) }\end{array}$} & \multicolumn{2}{|c|}{ Characteristics of surveillance program and methods } & \multirow[t]{2}{*}{ Results } \\
\hline & & Health surveillance & Health education & \\
\hline $\begin{array}{l}\text { Hurst et al, } \\
1979(9) \\
\text { United States }\end{array}$ & $\begin{array}{l}\text { Factory in Texas where asbestos } \\
\text { insulation products were manufac- } \\
\text { tured (1954-1972), extension to } \\
\text { other asbestos workers in the area }\end{array}$ & $\begin{array}{l}\text { Identification of } 1095 \text { previous } \\
\text { workers through health examina- } \\
\text { tion records and invitation to par- } \\
\text { ticipate } \\
\text { Questionnaire, physical examina- } \\
\text { tion, posteroanterior lung } X \text { rays, } \\
\text { left lateral view, sputum cytology, } \\
\text { respiratory function tests }\end{array}$ & Smokers, on an individual basis & Not presented \\
\hline $\begin{array}{l}\text { Felton } \\
1979(10) \\
\text { United States }\end{array}$ & $\begin{array}{l}\text { Long Beach naval shipyard, a facil- } \\
\text { ity of the United States Navy in Los } \\
\text { Angeles, opened in } 1943\end{array}$ & $\begin{array}{l}\text { In } 1977 \text {, all personnel offered a } \\
\text { chest X ray (6640 attendees, } \\
88.6 \% \text { of total); register estab- } \\
\text { lished for those with an X ray in- } \\
\text { dicative of asbestos-related disease } \\
\text { and known work history; program } \\
\text { planned on a yearly basis: each } \\
\text { worker leaving employment offered } \\
\text { a yearly examination }\end{array}$ & $\begin{array}{l}\text { Workers dealing with asbestos or } \\
\text { having asbestos-related diseases } \\
\text { (the latter: } 18.1 \% \text { ) were offered an } \\
\text { "educational effort" on the health } \\
\text { consequences of asbestos }\end{array}$ & Not presented \\
\hline $\begin{array}{l}\text { Li et al, } 1983 \\
1984(11,12) \\
\text { United States }\end{array}$ & $\begin{array}{l}\text { Naval shipyard in Charleston, } \\
\text { South Carolina }\end{array}$ & $\begin{array}{l}\text { Work history, smoking habits, pul- } \\
\text { monary function testing, chest } \\
\text { X ray, sputum cytology collected } \\
\text { for } 3991 \text { eligible civilian shipyard } \\
\text { workers }\end{array}$ & $\begin{array}{l}\text { All participants given a pamphlet } \\
\text { outlining a smoking cessation } \\
\text { strategy; smokers categorized as } \\
\text { having normal or abnormal pulmo- } \\
\text { nary status ( } 1231 \text { eligible, } 871 \text { par- } \\
\text { ticipants) encouraged to join a } \\
\text { smoking cessation study, ran- } \\
\text { domly assigned to receive a simple } \\
\text { warning of } 3-5 \text { min of behavioral } \\
\text { cessation counseling from a physi- } \\
\text { cian; smoking status of both } \\
\text { groups evaluated at } 3 \text { - and } 11 \text { - } \\
\text { month intervals }\end{array}$ & $\begin{array}{l}8.4 \% \text { still not smok- } \\
\text { ing } 11 \text { months after } \\
\text { behavioral counseling } \\
\text { compared with } 3.6 \% \\
\text { of those who received } \\
\text { a minimal warning } \\
\text { only }\end{array}$ \\
\hline $\begin{array}{l}\text { Tuch et al, } \\
1986(13) \\
\text { Israel }\end{array}$ & $\begin{array}{l}\text { Former workers in a cement-asbes- } \\
\text { tos plant }\end{array}$ & $\begin{array}{l}2800 \text { subjects invited by mail to an } \\
\text { interview on work history, medical } \\
\text { examinations, pulmonary function } \\
\text { tests }\end{array}$ & $\begin{array}{l}\text { Smoking cessation program of- } \\
\text { fered; method not presented }\end{array}$ & $\begin{array}{l}184 \text { attendees }(6.6 \%) \\
\text { no results on smok- } \\
\text { ing cessation }\end{array}$ \\
\hline $\begin{array}{l}\text { Tillet et al, } \\
1986(14), \\
\text { United States }\end{array}$ & $\begin{array}{l}\text { Three cohorts of asbestos workers, } \\
1 \text { of members of the Flint Glass } \\
\text { Workers' Union }\end{array}$ & $\begin{array}{l}\text { Periodical medical surveillance of- } \\
\text { fered to workers and family mem- } \\
\text { bers; } 854 \text { members identified and } \\
\text { notified }\end{array}$ & $\begin{array}{l}\text { Smoking cessation offered; } \\
\text { method not presented }\end{array}$ & $\begin{array}{l}\text { Particiption rate } 70 \% \text {; } \\
\text { results on smoking } \\
\text { not presented }\end{array}$ \\
\hline $\begin{array}{l}\text { Meyerowitz, } \\
1989(15) \\
\text { United States }\end{array}$ & $\begin{array}{l}\text { Workers in a plant in Minnesota for } \\
\text { at least } 5 \text { years and with at least } 15 \\
\text { years of latency }\end{array}$ & $\begin{array}{l}\text { Invited to attend screening and } \\
\text { educational program ( } 325 \text { invited, } \\
219 \text { attending) }\end{array}$ & $\begin{array}{l}\text { Educational program offered; } \\
\text { method not presented }\end{array}$ & Not presented \\
\hline $\begin{array}{l}\text { Kilburn } 1990 \\
\text { (16); Kilburn } \\
\text { \& Warshaw } \\
1992(17) \\
\text { United States }\end{array}$ & $\begin{array}{l}\text { Union members who were or had } \\
\text { been exposed to asbestos in con- } \\
\text { struction, metal trades, shipyards }\end{array}$ & $\begin{array}{l}\text { Selection of } 4183 \text { (out of } 8749 \\
\text { members) whose exposure had be- } \\
\text { gun } 15 \text { or more years earlier and } \\
\text { lasted at least } 5 \text { years; question- } \\
\text { naire, chest } X \text { ray, spirometry, and } \\
\text { measurement of alveolar carbon } \\
\text { monoxide }\end{array}$ & $\begin{array}{l}\text { Smoking cessation program of- } \\
\text { fered: (physician counseling) cur- } \\
\text { rent smokers ( } 2627 \text { subjects) } \\
\text { asked by mail about smoking sta- } \\
\text { tus } 6 \text { months later }\end{array}$ & $\begin{array}{l}\text { Subjects with lung } \\
\text { impairment appeared } \\
\text { more inclined to quit } \\
\text { smoking }\end{array}$ \\
\hline $\begin{array}{l}\text { Munafo et al } \\
1992(18) \\
\text { Italy }\end{array}$ & $\begin{array}{l}\text { Railroad workers at repair work- } \\
\text { shops with at least } 30 \text { d of work } \\
\text { between } 1960 \text { and } 1980\end{array}$ & $\begin{array}{l}14887 \text { invited, } 9303 \text { participants in } \\
1991 \text {; questionnaire on work his- } \\
\text { tory and smoking, medical exami- } \\
\text { nation, chest } X \text { ray, respiratory } \\
\text { function tests, asbestos bodies in } \\
\text { sputum used }\end{array}$ & & Not presented \\
\hline
\end{tabular}

exposure to asbestos and also to submit these subjects to health evaluations. Current smokers who accepted health examinations were encouraged to join a smoking cessation program. After completion of the first phase, however, no additional activities were foreseen.

The Norwegian program involved the population of a restricted area, where asbestos-exposed subjects were identified in a radiological screening program for tuberculosis. The program involved repeated radiological screening and monitoring of the smoking habits of asbestos-exposed subjects who were also smokers. This inter- vention study is the only population-based program from which evidence has been obtained of a reduced excess risk after the cessation of asbestos exposure and current smoking (33).

In Sweden and Israel $(36,37)$, programs involving asbestos workers have been suggested, but no information is available on further developments.

\section{Chemoprevention trials}

Chemoprevention can be defined as the use of specific natural or synthetic chemical agents to reverse, suppress, 
Table 2. Surveillance programs of exposure to asbestos at the national or subnational level.

\begin{tabular}{|c|c|c|c|c|}
\hline \multirow[t]{2}{*}{ Nation } & \multirow{2}{*}{$\begin{array}{l}\text { Initial } \\
\text { year }\end{array}$} & \multicolumn{2}{|l|}{ Description of program and methods } & \multirow[t]{2}{*}{ Results } \\
\hline & & Health surveillance & Health education & \\
\hline $\begin{array}{l}\text { United Kingdom } \\
\text { (England and Wales) } \\
(22-24)\end{array}$ & 1970 & $\begin{array}{l}\text { National program for workplaces subject to } \\
\text { the } 1969 \text { asbestos regulations; new work- } \\
\text { ers are to be examined during the 2nd } \\
\text { month of employment and every } 2 \text { years, as } \\
\text { long as they remain in that employment; } \\
\text { central record-keeping system; examination } \\
\text { consisted of collection of exposure history, } \\
\text { smoking habits and respiratory symptoms, } \\
\text { clinical examination, chest posteroanterior } \\
\text { X ray; all workers included in the mortality } \\
\text { study }\end{array}$ & Not quoted & $\begin{array}{l}\text { By end of } 1971,74767 \text { subjects included in } \\
\text { list; results of follow-up mortality study } \\
\text { (1971-1991) on } 57402 \text { demonstrated a } \\
\text { large excess of lung cancer and meso- } \\
\text { thelioma among those who started work be- } \\
\text { fore the asbestos regulations and a smaller } \\
\text { but statistically significant excess of lung } \\
\text { cancer among those who started work after } \\
\text { the regulations together with an important } \\
\text { number of deaths from mesothelioma; over- } \\
\text { all, the excess for lung cancer was confined } \\
\text { to smokers }\end{array}$ \\
\hline Germany $(25,26)$ & 1977 & $\begin{array}{l}\text { National program aimed at identifying fac- } \\
\text { tories exposing workers to asbestos and at } \\
\text { building up a list of asbestos-exposed work- } \\
\text { ers; insurance institutes asked workers to } \\
\text { attend medical examinations regularly (fre- } \\
\text { quency not stated) (questionnaire on work } \\
\text { history, chest } X \text { ray) }\end{array}$ & Not quoted & $\begin{array}{l}\text { During } 1987-1991,106984 \text { workers iden- } \\
\text { tified in } 7643 \text { registered companies; } 87028 \\
\text { subjects invited to attend a medical exami- } \\
\text { nation; mortality follow-up ( } 1977-1988 \text { ) of } \\
\text { a subcohort alive at the beginning of the } \\
\text { study, }>3 \text { years of exposure, and older than } \\
30 \text { years and validation of accuracy of cause } \\
\text { of death reported on death certificates }\end{array}$ \\
\hline Finland $(27-29)$ & 1989 & $\begin{array}{l}\text { As part of a general program to prevent as- } \\
\text { bestos hazards, screening for asbestos-re- } \\
\text { lated diseases, aimed at building up list of } \\
55000 \text { presumably asbestos-exposed } \\
\text { workers, throuah identification and answers }\end{array}$ & $\begin{array}{l}\text { Information offered at } \\
\text { examinations and of- } \\
\text { fer to join a smoking } \\
\text { cessation group }\end{array}$ & $\begin{array}{l}24000 \text { questionnaires mailed; } 18943 \text { sub- } \\
\text { jects examined, } 4133(21.8 \%) \text { positive } \\
\text { tests (lung fibrosis, pleural plaques or } \\
\text { thickenings) }\end{array}$ \\
\hline
\end{tabular}
to fulfilling the criteria invited to attend medical examinations including exposure history and chest $X$ ray; all positive $X$ rays referred to specialized centers for further examinations

Norway, 1982 After collection of work history in 1982, ascounty of

Telemark bestos-exposed male workers identified in cross-sectional population-based screening for tuberculosis (involving 28216 subjects); categorized by level of risks for specific diseases, each becoming the target for "riskbased intervention" based on counseling to stop smoking and attend screening programs involving lung $X$ ray every 4 months and annual exfoliative cytology if aged $50-$ 69 years and at high lung cancer risk; biannually for lower risk category

Information given to smokers by physicians or nurses: counseling on potential lung cancer risk reduction if smoking stopped
Results of follow-up at 8 years (19821989) comparing those attending (subdivided according to smoking and asbestos exposure) and not attending screening; reduced lung cancer risk reported for subjects stating they had ceased smoking more than 12 years earlier at the time of screening or prevent carcinogenic progression to invasive cancer. The definition does not include compounds ingested as part of the normal diet (38); instead the agents are added to a person's usual regimen.

Most of the chemoprevention trials initiated during the last decade involved the testing of micronutrients for possible preventive effects against epithelial cancers (39). This rationale is based on the results of observational studies and laboratory experiments, which showed that certain human dietary habits and the administration of some micronutrients to animals are associated with low risks for cancer of several organs, including the lung, and inhibition of carcinogenic processes in animals $(40,41)$. One of the most promising micronutrients for cancer prevention is beta-carotene, because of evidence of its possible antioxidant action. Four chemoprevention trials based on beta-carotene and on retinol ( 3 trials) or other potential chemopreventive agents (1 trial) involved asbestos-exposed workers, alone or together with other high-risk groups (42-61). The chemoprevention trials on asbestos workers are summarized in table 3 .

Three trials were fully randomized. One, the Beta Carotene and Retinol Efficacy Trial (CARET), was a placebo-controlled primary prevention trial with a betacarotene and retinol treatment group, and one, the Australian study, was based on randomization of subjects into 2 treatment groups, with no placebo group. In the latter study, base-line end-point rates were estimated from those for the general exposed population.

The McLarty trial addressed workers heavily exposed mainly to amosite (42); the Australian study involved workers exposed exclusively to crocidolite (62). The CARET trial involved asbestos-exposed subjects who were also current smokers or who had smoked during the last 15 years. Two trials (the CARET and Australian studies) aimed at testing the potential preventive action of treatment on both lung cancer and mesothelioma, while the McLarty study evaluated the effect on lung 
Table 3. Chemoprevention trials involving workers exposed to asbestos. (TPA = tissue popypeptide antigen, CEA = carcinoembryonic antigen)

\begin{tabular}{|c|c|c|c|c|c|c|c|c|}
\hline Reference & Enrolled population & $\begin{array}{l}\text { Current } \\
\text { exposure to } \\
\text { asbestos }\end{array}$ & Study design & End point & Regimen & $\begin{array}{l}\text { Other } \\
\text { strategies }\end{array}$ & $\begin{array}{l}\text { Plasma levels } \\
\text { after treatment }\end{array}$ & $\begin{array}{l}\text { Current status of } \\
\text { results }\end{array}$ \\
\hline $\begin{array}{l}\text { McLarty, } \\
1992 \& 1995 \\
(42-44) \\
\text { United States }\end{array}$ & $\begin{array}{l}755 \text { men at asbestos } \\
\text { factories or asbestos } \\
\text { workers in Texas }\end{array}$ & Undefinable & $\begin{array}{l}\text { Randomized } \\
\text { double-blind, } \\
\text { placebo- } \\
\text { controlled }\end{array}$ & Sputum atypia & $\begin{array}{l}\text { Beta-carotene } \\
50 \mathrm{mg} / \mathrm{day} \\
\text { retinol, } 25 \text { 000 IU } \\
\text { on alternate days }\end{array}$ & None & $\begin{array}{l}\text { Beta-carotene } \\
5-6 \text { times base } \\
\text { line; retinol } \\
\text { no significant } \\
\text { difference }\end{array}$ & $\begin{array}{l}\text { No significant } \\
\text { difference } \\
\text { between } \\
\text { treatment and } \\
\text { placebo }\end{array}$ \\
\hline $\begin{array}{l}\text { Beta-carotene } \\
\text { and retinol } \\
\text { efficacy trial } \\
\text { (CARET) } \\
1988-1996 \\
(45-57) \text {, } \\
\text { United States }\end{array}$ & $\begin{array}{l}4060 \text { asbestos- } \\
\text { exposed men, aged } \\
45-69 \text { years, } \\
\text { current or ex- } \\
\text { smokers ( } 14254 \\
\text { heavy smokers or } \\
\text { recent ex-smokers) }\end{array}$ & Yes & $\begin{array}{l}\text { Factorial, pilot; } \\
\text { randomized, } \\
\text { placebo }\end{array}$ & $\begin{array}{l}\text { Lung cancer and } \\
\text { mesothelioma }\end{array}$ & $\begin{array}{l}\text { Beta-carotene, } \\
50 \mathrm{mg} / \text { day; } \\
\text { retinol, } \\
25000 \mathrm{lU} / \mathrm{day} ; \\
\text { both; placeb }\end{array}$ & $\begin{array}{l}\text { Antismoking } \\
\text { advice }\end{array}$ & $\begin{array}{l}\text { Both chemicals } \\
6-7 \text { times } \\
\text { base line }\end{array}$ & $\begin{array}{l}\text { Both chemicals: } \\
\text { excess lung } \\
\text { cancer, general } \\
\text { and cardio- } \\
\text { vascular mortality } \\
\text { (asbestos workers } \\
\text { and smokers) }\end{array}$ \\
\hline $\begin{array}{l}\text { Musk, } \\
1994(58,59) \\
\text { Australia }\end{array}$ & 1024 ex-miners & No & $\begin{array}{l}\text { Randomized } \\
\text { between } 2 \\
\text { treatments; no } \\
\text { placebo }\end{array}$ & $\begin{array}{l}\text { Lung cancer and } \\
\text { mesothelioma }\end{array}$ & $\begin{array}{l}\text { Beta-carotene, } \\
30 \mathrm{mg} / \text { day; } \\
\text { retinol, } \\
25000 \text { IU/day }\end{array}$ & Undefinable & Undefinable & $\begin{array}{l}\text { Preliminary: lower } \\
\text { lung cancer and } \\
\text { mesothelioma } \\
\text { rates in retinol } \\
\text { compared with } \\
\text { beta-carotene } \\
\text { group }\end{array}$ \\
\hline $\begin{array}{l}\text { Pluygers, } \\
1991-1992 \\
(60,61) \\
\text { France }\end{array}$ & $\begin{array}{l}300 \text { asbestos-cement } \\
\text { workers }\end{array}$ & Yes & $\begin{array}{l}\text { Randomized into } \\
\text { those positive for } \\
\text { biomarkers; TPA, } \\
>200 \mathrm{U} / \mathrm{l} \text {; ferritin, } \\
>400 \mathrm{ng} / \mathrm{lt} \text {; CEA, } \\
>3 \mathrm{ng} / \mathrm{ml}\end{array}$ & $\begin{array}{l}\text { Asbestos-related } \\
\text { malignancies }\end{array}$ & $\begin{array}{l}\text { Acetyl-cysteine } \\
\text { (600 mg/day), } \\
\text { beta-carotene } \\
\text { (30 mg/day), } \\
\text { selenium } \\
(100 \mu \mathrm{\mu g} / \text { day), } \\
\text { alpha-tocopherol } \\
\text { ( } 30 \mathrm{mg} / \text { day), } \\
\text { ascorbic acid } \\
\text { (20 mg/day), } \\
\text { riboflavin } \\
\text { (20 mg/day) }\end{array}$ & None & Not reported & On-going \\
\hline
\end{tabular}

cancer by assessing the frequency of an early lesion, sputum atypia. The French study uses "asbestos-associated malignancies" as end points, defined on the basis of serum biomarkers (tissue polypeptide antigen, carcinoembryonic antigen, serum hyaluronic acid and ferritin) $(60,61)$. Two trials (the CARET and Australian studies) reported power estimations for the lung cancer end point, while one (McLarty) was based on smaller numbers because of the higher frequency of the end point.

Two chemoprevention trials involved cohorts of asbestos workers who had been identified earlier and followed for cancer risk. They were workers at an asbestos factory in Texas, summarized in table 1 (9), and crocidolite miners in Wittenoom, Australia (62). The 4 trials have the use of beta-carotene as a preventive agent in common, but the administered dose varied from 30 to 50 $\mathrm{mg} /$ day. Retinol was also administered in 3 trials, at doses from $25000 \mathrm{IU}$ on alternate days to $25000 \mathrm{IU} /$ day. The factorial design of the CARET trial should allow an evaluation of the effect of retinol independently of that of beta-carotene.

In the CARET study, all the subjects were offered participation in a special program to stop smoking, and $30 \%$ abstinence was observed after 2 years, the abstinence being equally distributed between the 2 groups of the study. In the French study, dietary advice was given to increase fruit and vegetable intake.
The base-line results of the McLarty study showed that the serum levels of beta-carotene were increased in the treated group. This finding suggests that there was adequate compliance. The retinol serum levels did not vary significantly between the 2 groups, but the administered dose was low (25 000 IU on alternate days), with the stated aim of limiting metabolic conversion of betacarotene to retinol. The blood levels of beta-carotene were lower in the smokers and drinkers in both groups of the study. The end point of the study, sputum atypia, was not affected by the treatment (44).

The CARET study was interrupted after an average of 4 years' supplementation because of adverse results in the interim analysis. Treatment significantly modified the plasma levels of both beta-carotene and retinol (55), but combined treatment significantly increased the incidence of lung cancer $(5.92 \times 1000$ versus $4.62 \times 1000)$ and mortality from all causes $(14.45 \times 1000$ versus $11.91 \times 1000$ ) and cardiovascular disease in comparison with the group receiving the placebo. The results for the asbestos-exposed subjects did not differ from those for smokers, although the excess lung cancer incidence found in this subgroup was not significant because of the small numbers $(6.05 \times 1000$ versus $4.33 \times 1000$, $\mathrm{P}=0.08)(57)$.

Very preliminary results from the chemoprevention trial in Australia, comparing groups treated with retinol and beta-carotene, indicate slightly fewer lung cancers 
and mesotheliomas in the retinol group, there being 4 lung cancers and 3 mesotheliomas in the retinol group, 6 lung cancers and 12 mesotheliomas in the beta-carotene group (de Klerk N, personal communication). Even if this difference is confirmed, however, the possible effect of beta-carotene in comparison with base-line rates should be taken into account.

The French study is still in progress.

\section{Discussion}

\section{Surveillance programs in factories}

The sources used to identify the studies may not have been adequate, and the number of surveillance studies on asbestos workers and on smoking cessation programs may have been underestimated. Those that were identified suggest, however, that few long-term surveillance programs on asbestos-exposed workers have been carried out in factories or industrial sectors, and those reported involve a limited number of workers. Furthermore surveillance studies are too often restricted to the period of actual exposure. When factories are closed or workers retire or leave the workplace, health authorities are often unable to take over the surveillance activities performed in factories, and workers who were previously the target of health examinations automatically become "lost to follow-up". Lists of exposed subjects are usually unavailable or are not sent to the health authorities, since this is not a legal requirement in most countries.

Most programs to survey asbestos workers can be defined as "passive", as they consist of (repeated) follow-up of the same cohort over time to evaluate mortality, but no "active" intervention is undertaken. Ascertainment of vital status does not require any direct contact between subjects and the health structure. Few surveillance programs include activities other than simple medical surveillance, such as smoking cessation programs. Furthermore, the published protocols on the activities are limited (7), and even fewer results have been published on their efficacy.

\section{National surveillance programs}

Europe is the only area of the world where surveillance programs on asbestos workers have been carried out at the national level. The experiences vary by country. A common denominator, which makes these programs possible, is the availability of a national record-keeping system based on the transmission of lists of asbestos-exposed workers to health authorities. All of the programs that have evaluated the cancer experience of asbestos workers show high rates of respiratory cancer, even among subjects, like those in the United Kingdom, who were hired after the application of a new hygiene standard.

Only the Finnish and Norwegian programs included health education. Current smokers who accepted health examinations were encouraged to join a smoking cessation program. After 8 years of follow-up, a reduction in lung cancer was observed among people who gave up smoking in Norway.

Industrialized nations should have national "asbestos" programs to eliminate the hazards of asbestos, including a policy for surveillance and intervention among currently and formerly exposed workers. Few countries have developed such a policy, although the congressional mandate on shipyard workers in the United States and the Italian policy for railroad workers (table 1) may be considered surrogates limited to workers involved in some industrial sectors

The European Community, within the framework of the regulation on occupational exposure to asbestos (which did not include a ban on asbestos use already applied in several member countries), approved a directive $(83 / 477 / \mathrm{CEE})$ that requires lists to be kept of exposed workers at the national level, with the aim of encouraging health surveillance beyond the cessation of employment. No data are yet available about the implementation of the directive in member states.

\section{Chemoprevention trials}

Chemoprevention trials involving asbestos-exposed workers have encountered several problems. In the CARET study, asbestos-exposed subjects were chosen as a high-risk group for lung cancer, together with heavy smokers, on the basis of the hypothesis that micronutrients prevent carcinogenic processes due to various carcinogenic agents. In fact, the effect was comparable in the 2 groups of subjects at risk, with an increased risk for mortality from both lung cancer and cardiovascular diseases. This result is consistent with that found for heavy smokers in another large chemopreventive trial involving beta carotene (63), while an American trial with physicians who were mostly nonsmokers and were given a lower dose of beta-carotene showed no effect on lung cancer incidence (64).

Because of lack of power it is difficult to evaluate the effect on mesothelioma in the 2 trials (the CARET and Australian studies) that considered this neoplasm as an outcome. The available observational and experimental evidence of a possible preventive effect of micronutrients on nonepithelial cancers, and specifically on mesotheliomas, is very weak (65). An evaluation of the independent effect of retinol in the CARET study (the only study that could conduct such an evaluation) has not yet been reported. The McLarty trial provides substantially negative results with regard to squamous-cell atypia; the 
small numbers and the short follow-up prevent comparison of the results for mortality from lung cancer and cardiovascular disease with those of the CARET study.

Of the on-going trials, the French one is the most problematic. In this trial, laboratory tests are being used to identify subjects who have or may develop asbestosrelated malignancies, but no convincing validation of their predictive value in terms of end point has been given $(60,61)$. Treatment is a mixture of drugs, some of which have not been shown to have preventive potential The period of treatment, the end points, and the monitoring of side-effects have not been clearly described, and the power estimate of the study has not been reported. This trial involves workers still exposed to asbestos, as does, at least partially, the CARET study, and no clear strategy for ceasing or at least reducing current exposure has been given. The Australian and McLarty studies address only previously exposed workers; however, the incompletely randomized design of the Australian study (no placebo group) leaves some doubt about the interpretation of the results. As the treatment is practically identical to that used in the CARET study, any differences in the results from this study would need validation.

The results of the aforementioned studies should be interpreted by comparing them with those of other chemoprevention trials using the same agents and similar end points. The consistency of the CARET trial and that described by The Alpha-tocopherol, Beta-carotene Cancer Prevention Study Group (63) and their compatibility with the Physicians Health Study (64) suggest that the beta-carotene hypothesis for preventing lung cancer in asbestos-exposed workers should be abandoned, as it has for other high-risk groups (57). The results of the McLarty study lead in the same direction. The effect of retinol has not yet been evaluated, but some results should appear from the CARET trial, now in its analytical phase. It would seem wise, after the experience with beta carotene, not to begin new trials with retinol before the CARET results have been made available. The evidence for an effect of any chemopreventive agent on mesotheliomas is currently inadequate to justify randomized trials.

Only some of the trials included a program on smoking cessation, and only the French trial considered the opportunity of dietary counseling (but not antismoking advice). This lack of concomitant strategies and the lack of action to decrease any current exposure to asbestos are critical, especially in light of the frustrating results of chemoprevention (66).

The main problem in developing a proper strategy for a second generation of prevention trials is that the mechanisms of asbestos carcinogenesis are not yet clearly understood (67). Asbestos is currently considered to give rise to all histological types of lung cancer (68-71), and asbestos fibers may act at multiple stages in neoplastic development (72). These fibers have been shown to induce metaplasia in tracheobronchial epithelium (73) and to alter the expression of the proto-oncogenes that regulate the proliferation of epithelial cells (74). The role of asbestos fibers in the latter stages of tumor progression is unknown. Macrophages are the initial target cells of asbestos fibers. Phagocytosis of the fibers is accompanied by the activation of macrophages, which results in the secretion of a variety of chemical mediators and cytokines. These mediators amplify local inflammatory reactions, which also involve the production of reactive oxygen and nitrogen oxide intermediates. Growth factors for epithelial cells and fibroblasts, such as tumor growth factor-alpha and platelet-derived growth factor, are also released from activated macrophages. It has been hypothesized that an imbalance between cytokines and growth factors may contribute to the pathological effects of asbestos fibers, especially to asbestosis (75). They may also play a role in the multistage carcinogenesis process.

\section{Concluding remarks}

The carcinogenic risks related to exposure to asbestos fibers in industrial settings remained unrecognized for a long time, as, until the 1970 s, the few existing hygienic standards were limited to preventing the occurrence of lung fibrosis. The standards were not effective, as evidenced by the high prevalence of lung fibrosis and pleural plaques detected for the workers enrolled in the surveillance studies and trials reviewed in this article. A second effect of the limited efficacy of the standards is that asbestos-related cancers have received insufficient compensation (76)

Repeated health examinations, lung X rays, and functional tests to detect asbestos-related lung diseases in the work force were offered regularly in several countries and often imposed by law. The health examinations were usually restricted to the period of employment, however, even though the long latency before the development of lung damage was known. This attitude is inconsistent with the statement that "screening for risk identification presupposes a medical care system which is able to provide continuity of long-term personal care for everyone [p 35]" (77). As a consequence, no evaluation has been published of the effectiveness of periodic examinations in slowing the natural course of fibrosis or in increasing survival. In the countries that recognize the carcinogenic risks due to exposure to asbestos and which have limited or banned the use of asbestos, the policy of periodically examining workers for health effects can be implemented without the criticism that the authorities are choosing "not to attack the situations that determine exposure [p 47]" (77).

With regard to screening for lung cancer, the available evidence goes against the hypothesis that lung can- 
cer mortality is reduced significantly by screening based on chest $X$ rays. With the exception of the program in Norway, no attempt is under way to screen workers who have previously been exposed to asbestos for lung cancer. Instead, most of the surveillance programs including the period after exposure have been designed to observe events, rather than to reduce the cumulative risk. It is still not clear whether the cancer risks of active workers who have accumulated relevant exposure can be reduced by eliminating or reducing their current exposure to asbestos $(78-80)$. A reduction in cancer risk would be more plausible if preventive action were not confined to a single factor. The limited diffusion of smoking cessation and dietary programs in the on-going surveillance programs is startling.

The information necessary for planning intervention programs properly includes estimates of the decline in risk after the cessation of exposure among smokers and nonsmokers and the decline in risk for smokers who stop smoking. These data could be obtained by follow-up of target populations after the cessation of exposure(s). Application of this strategy to large cohorts of smokers has helped determine the patterns of decreasing risk after smoking cessation (81-86). A similar effort should be pursued for asbestos workers, for whom information on health status and smoking habits is becoming available. A better integration of the programs being carried out in Europe could also offer an opportunity to incorporate smoking cessation activities.

The results of chemoprevention studies suggest that chemoprevention is not a viable option for asbestosexposed workers, as the trials published so far on the use of beta-carotene and other supplementations thus far tested have provided no evidence of protection.

\section{Acknowledgments}

The authors thank Elisabeth Heseltine, MSc, for editing the manuscript. The work was partially supported by a grant of the Italian Association for Cancer Research (AIRC) and BIOMED-2 (BM4-CT95-1100).

\section{References}

1. Selikoff IJ, Hammond EC, Churg J. Asbestos exposure, smoking and neoplasia. JAMA 1968;204:106-12.

2. Vainio H, Boffetta P. Mechanisms of the combined effect of asbestos and smoking in the etiology of lung cancer. Scand J Work Environ Health 1994;20:235 - 42 .

3. Langård S. Proposal for future uses in epidemiology for cohort studies on the prevention of work-related cancer. Scand J Work Environ Health 1992;18 suppl 1:57—63.

4. Hemminki K, Vainio H. Human exposure to potentially carcinogenic compounds. In: Berlin A, Draper M, Hemminki K,
Vainio $\mathrm{H}$, editors. Monitoring human exposure to carcinogenic and mutagenic agents. Lyon: International Agency for Research on Cancer, 1984:37-45. IARC scientific publication no 59 .

5. Greenland P, Sondik EJ, editors. Cancer control objectives for the nation: 1985-2000. Bethesda (MD): National Cancer Institute (NCI), 1986. NCI monograph no 2.

6. Parkin DM, Pisani P. Screening for lung cancer. In: Miller $\mathrm{AB}$, editor. Advances in cancer screening. Boston (MA): Kluwer, 1996: 121-8. Cancer treatment and research series.

7. Schwartz JL. Review and evaluation of smoking cessation methods. Washington (DC): National Institute of Health (NIH), 1987. NIH publ no 87—2940.

8. Pederson LL. Cessation treatment for respiratory diseases patients. In: Hirsch A, Goldberg M, Martin J, Masse R, editors. Prevention of respiratory diseases. New York (NY): M Dekker, 1993:583-606.

9. Hurst GA, Spivey CG, Matlage WT, Miller JM, Faulk G, Hieger LR, et al. The Tyler asbestos worker program: I. a medical surveillance model and method. Arch Environ Health 1979;34:432-9.

10. Felton JS. A comprehensive program in asbestos hazard surveillance and education. Am Ind Hyg Assoc 1979;40:11 - 8.

11. Li VC, Kim YJ, Terry PB, Curthie JC, Roter D, Emmett EA, et al. Behavior, attitudinal, and physiologic characteristics of smoking and non smoking asbestos-exposed shipyard workers. J Occup Med 1983;25:864-70.

12. Li VC, Kim YJ, Ewart CK, Terry PB, Cuthie JC, Wood J, et al. Effects of physician counseling on the smoking behavior of asbestos-exposed workers. Prev Med 1984;13:462 - 76.

13. Tuch H, Tulchinsky TH, Casper M, Knaane H. Medical screening of former asbestos cement workers in Israel: a pilot program. Am J Ind Med 1986;10:471-8.

14. Tillet S, Ringen K, Schulte P, McDougall V, Miller K, Samuels S. Interventions in high-risk occupational cohorts: a crosssectional demonstration project. J Occup Med 1986;28:71927.

15. Meyerowitz BE, Sullivan CD, Premeau CL. Reactions of asbestos-exposed workers to notification and screening. Am J Ind Med 1989;15:463-75.

16. Kilburn KH, Warshaw RH. Effects of individually motivating smoking cessation in male blue collar workers. Am J Publ Health 1990;80:1334-7.

17. Kilburn KH, Warshaw RH. Severity of pulmonary asbestosis as classified by International Labour Organisation profusion of irregular opacities in 8749 asbestos-exposed American workers. Arch Intern Med 1992;152:325 - 7

18. Munafo' E, Riboldi L, Pesatori A, Paba G, Chiappino G. Sorveglianza sanitaria in una coorte di esposti ad amianto nelle Officine Grandi Riparazioni FS: il programma e i risultati preliminari. In: Battista G, Giglioli S, Longini L, editors. Atti del seminario internazionale aggiornamenti in tema di neoplasie polmonarie. Pisa (Italy): Ed Universitaria Litopratia Felici, 1992:571-9.

19. Stanbury MS, Rosemann KD. A methodology for identifying workers exposed to asbestos since 1940. Am J Public Health 1987;77:854-5.

20. Meredith SK, Taylor VM, McDonald JC. Occupational respiratory disease in the United Kingdom 1989: a report to the British Thoracic Society and the Society of Occupational Medicine by the SWORD project group. Br J Ind Med 1991;48: 292-8.

21. Henneberger PK, Stanbury MJ. Patterns of asbestosis in New Jersey. Am J Ind Med 1992;21:689—97. 
22. Smither WJ. Surveillance of high-risk groups: a survey of asbestos workers, the present position in the United Kingdom. Ann NY Acad Sci 1979;330:525 - 32 .

23. Hodgson JT, Jones RD. Mortality of asbestos workers in England and Wales 1971-1981. Br J Ind Med 1986;43:158-64.

24. Hutchings S, Jones J, Hodgson J. Asbestos-related diseases. In: Drever F, editor. Occupational health: decennal supplement. London: London Office of Population Censuses and Surveys, 1995:127-52. HMSO, series DS no 10.

25. Lehnert G, Raithel J, Valentin $H$. Asbestfeinstaubexposition, asbestose und lungenkrebbs. Arbeitsmed Sozialmed Paeventivmed 1992;27:96-101.

26. Rösler JA, Lange H, Woitowitz RH, editors. Asbesteinwirkung am Arbeitsplatz und Sterblichkeit an bösartigen Tumoren in der Bundesrepublik Deutschland. Sankt Augustin: Hauptverband der gewerblichen Berufsgenossenschaften (Germany): 1993. Forschungbericht Asbest IV.

27. Huuskonen MS, Karjalainen A, Koskinen K, Rinne JP, Tossavainen A, Rantanen J. Asbestos program 1987- 92: final report. 2nd ed. Helsinki: Institute of Occupational Health, 1994.

28. Huuskonen MS. Screening for occupational cancer. Scand J Work Environ Health 1992;18 suppl 1:110-4.

29. Koskinen K, Rinne J, Zitting A, Tossavainen A, Kivekäs J, Reijula K, et al. Screening for asbestos-induced diseases in Finland. Am J Ind Med 1996;30:241 —51

30. Hilt B, Langård S, Lund-Larsen PG, Lienm JT. Previous asbestos exposure and smoking habits in the county of Telemark, Norway: a cross-sectional population study. Scand J Work Environ Health 1986;12:561-6.

31. Hilt B, Lien JT, Lund-Larsen PG, Lund K, Langård S. Asbestos-related findings in chest radiographs of the male population of the county of Telemark, Norway: a cross-sectional study. Scand J Work Environ Health 1986;12:567-73.

32. Langård $\mathrm{S}$. Programme for intervention against asbestos related diseases in the county of Telemark, Norway. In: United States Department of Health and Human Services (DHHS). Proceedings of the VII International Pneumoconiosis Conference; August 23-26, 1988. Pittsburg (PA): United States Department of Health and Human Services (DHHS), 1990: $782-5$.

33. Waage HP, Langård S, Andersen A. The incidence of asbestos-related cancer in a population cross-section: eight year of follow-up. J Occup Med Toxicol 1993;1:15-29.

34. Langåd S. Prevention of lung cancer through the use of knowledge on asbestos and other work-related causes - Norwegian experiences. Scand J Work Environ Health 1994;20 special issue: $100-7$.

35. Langård S. Identification and prevention of work- and environment-related individual a priori disease risks. In: Mehlman MA, Upton A, editors. The identification and control of environmental and occupational diseases, part II. Adv Mod Environ Toxicol 1994;23:21-32.

36. Arbetsmarknads-Departmentet. Handlingsprogram mot asbest: delrapport avgiven av asbestkommissionen [Program on asbestos: partial report by the Commission on Asbestos]. Stockholm: 1986. Regeringskansliets offsetcentral Ds A 1985:5.

37. Ribak $\mathbf{J}$, Lerman $Y$. Use of asbestos in expected and unexpected places in Israel. Public Health Rev 1995;23:35-45.

38. Lippman SM, Benner SE, Ki Hong W. Cancer chemoprevention. J Clin Oncol 1994;4:851 - 73 .

39. Buiatti $\mathrm{E}$. Intervention trials of cancer prevention: results and new research programmes. Lyon: International Agency for Research on Cancer (IARC), 1994. Technical report no 18.
40. Greenwald P, Nixon DW, Malone WF, Kelloff GJ, Stern HR, Witkin KM. Concepts in cancer chemoprevention research. Cancer 1990;65:1883-90.

41. Buring JE, Hennekens CH. Current issues in cancer chemoprevention. In: Hakama M, Beral V, Cullen JW, Parkin DM, editors. Evaluating effectiveness of primary prevention of cancer. Lyon: International Agency for Research on Cancer (IARC), 1990:185 93. IARC scientific publications no 103.

42. McLarty JW. An intervention trial in high-risk asbestos-exposed workers. Adv Exp Med Biol 1992;320:141—9.

43. McLarty JW. An intervention trial in high-risk asbestos-exposed persons. In: Newell GR, Hong WK, editors. The biology and prevention of aerodigestive tract cancers. New York (NY): Plenum Press, 1992:141-9.

44. McLarty JW, Holiday DB, Girard WM, Yanagihara RH, Kummet TD, Greenberg SD. $\beta$-carotene, vitamin A, and lung cancer chemoprevention: results of an intermediate endpoint study. Am J Clin Nutr 1995;62:1431S-8S.

45. Omenn GS, Goodman GE, Kleinman GD, Rosenstock L, Barnhart S, Feigl $P$, et al. The role of intervention studies in ascertaining the contribution of dietary factors in lung cancer: the Seattle chemoprevention trial of retinoids in asbestosexposed workers. Ann NY Acad Sci 1988;534:575-83.

46. Omenn GS. A double-blind randomized trial with beta-carotene and retinol in persons at high risk of lung cancer due to occupational exposure to asbestos and/or cigarette smoking. Public Health Rev 1988;16:99—125.

47. Omenn GS, Goodman G, Grizzle J, Thornquist M, Rosenstock L, Barnhart $S$, et al. CARET, the $\beta$-carotene and retinol efficacy trial to prevent lung cancer in asbestos-workers and in smokers. AntiCancer Drugs 1991;2:79-86.

48. Grizzle J, Omenn G, Goodman G, Thornquist M, Rosenstock $\mathrm{L}$, Barnhart J, et al. Design of the beta-carotene and retinol efficacy trial (CARET) for chemoprevention of cancer in populations at high risk: heavy smokers and asbestos-exposed workers. In: Pastorino U, Hong WK, editors. Chemoimmuno Prevention of Cancer. New York (NY): GT Verlag Ed, 1991: $167-76$.

49. Omenn GS, Goodman G, Grizzle J, Thornquist M, Rosenstock $L$, Barnhart $S$, et al. Recruitment for the $\beta$-carotene and retinol efficacy trial (CARET) to prevent lung cancer in smokers and in asbestos-exposed workers. West J Med 1992; $156: 540-4$

50. Goodman GE, Omenn GS, CARET coinvestigators and staff. Carotene and retinol efficacy trial: lung cancer chemoprevention trial in heavy cigarette smokers and asbestos-exposed workers. In: Newell GR, Hong WK, editors. The biology and prevention of aerodigestive tract cancers. New York (NY): Plenum Press, 1992:137-40.

51. Omenn GS, Goodman GE, Thornquist MD, Rosenstock L, Barnhart S, Gylys-Colwell I, et al. The beta-carotene and retinol efficacy trial (CARET) to prevent lung cancer in highrisk populations: pilot study with asbestos-exposed workers. Cancer Epidemiol Biomarkers Prev 1993;2:381-7.

52. Goodman GE, Ommen GS, Thornquist MD, Lund B, Metch $\mathrm{B}$, Gysyl-Colwell I. The carotene and retinol efficacy trial (CARET) to prevent lung cancer in high-risk populations: pilot study with cigarette smokers. Cancer Epidemiol Biomarkers Prev 1993;2:389-96.

53. Thornquist MD, Omenn GS, Goodman GE, Grizzle JE, Rosenstock L, Barnhart $\mathrm{S}$, JH, et al. Statistical design and monitoring of the carotene and retinol efficacy trial (CARET). Control Clin Trials 1993;14:328-4.

54. Thornquist MD, Urban N, Tseng A, Edelstein C, Lund B, 
Omenn GS. Research cost analyses to aid in decision making in the conduct of a large prevention trial, CARET: carotene and retinol efficacy trial. Control Clin Trials 1993;14:32539.

55. Goodman GE, Metch BJ, Omenn GS. The effect of long-term $\beta$-carotene and vitamin $\mathrm{A}$ administration on serum concentrations of $\alpha$-tocopherol. Cancer Epidemiol Biomarkers Prev 1994;3:429-32.

56. Omenn GS, Goodman G, Thornquist M, Grizzle J, Rosenstock $\mathrm{L}$, Barnhart $\mathrm{S}$, et al. The $\beta$-carotene and retinol efficacy trial (CARET) for chemoprevention of lung cancer in high risk populations: smokers and asbestos-exposed workers. Cancer Res 1994;54:2038s_-43s.

57. Omenn GS, Goodman GE, Thornquist MD, Balmes J, Cullen MR, Glass A, et al. Effects of a combination of $\beta$-carotene and vitamin $A$ on lung cancer and cardiovascular disease. $N$ Engl J Med 1996;334:1150—5.

58. Musk AV, Hobbs MST, de Klerk NH. Prevention of malignant disease among workers exposed to crocidolite at Wittenoom Gorge. In: Sankaranarayanan R, Wahredorf J, Demaret $\mathrm{E}$, editors. Directory of on-going research in cancer epidemiology. Lyon: International Agency for Research on Cancer, 1994:16. IARC scientific publications no 130.

59. de Klerk NH, Ambroini G, Musk AW, Eccles JL, Hansen J, Hobbs MST. Measures of vitamin A intake in subjects with past exposure to asbestos. Presented at the IEA Thirteenth Scientific Meeting, New Pathways in Epidemiology, 26-29 September, Sydney.

60. Pluygers E, Baldewyns $P$, Minette $P$, Beauduin $M$, Gourdin $P$, Robinet $\mathrm{P}$. Biomarker assessments in asbestos-exposed workers as indicators for selective prevention of mesothelioma or broncogenic carcinoma: rationale and practical implementations. Eur J Cancer Prev 1991;1:57—68.

61. Pluygers E, Baldewyns $P$, Minette $P$, Beauduin $M$, Gourdin $P$, Robinet P. Biomarker assessments in asbestos-exposed workers as indicators for selective prevention of mesothelioma or broncogenic carcinoma: rationale and practical implementations. Eur J Cancer Prev 1992;1:129-38.

62. Musk AW, de Klerk NH, Eccles JL, Hobbs MST, Armstrong BK, Layman L, et al. Wittenoom, Western Australia: a modern industrial disaster. Am J Ind Med 1992;21:735-47.

63. The Alpha-Tocopherol, Beta-Carotene Cancer Prevention Study Group. The effect of vitamin $\mathrm{E}$ and beta-carotene in the incidence of lung cancer and other cancer in male smokers. $\mathrm{N}$ Engl J Med 1994;330:1029-35.

64. Hennekens CH, Buring JE, Manson JE, Stampfer M, Rosner $B$, Cook NR, et al. Lack of effect of long-term supplementation with beta-carotene on the incidence of malignant neoplasms and cardiovascular disease. N Engl J Med 1996;334: $1145-9$.

65. Muscat JE, Huncharek M. Dietary intake and the risk of malignant mesothelioma. Br J Cancer 1996;73:1122 - 5.

66. Tomatis L. Ethical aspects of prevention [review]. Scand J Work Environ Health 1995;21:245-51.

67. Boffetta P, Kane A, Saracci R, Wilbourn J, editors. Mechanisms in fibers carcinogenesis. Lyon: International Agency for Research on Cancer (IARC), IARC scientific publications. In press.

68. Mollo F, Piolatto G, Bellis D, Andrion A, Delsedime L, Bernardi $P$, et al. Asbestos exposure, and histologic cell types of lung cancer in surgical and autopsy series. Int J Cancer 1990; 46:576-80.
69. Cagle PT. Tumours of the lung (excluding lymphoid tumours). In: Thurlbeck WM, Churg AM, editors. Pathology of the lung. 2nd ed. New York (NY): Thieme Medical Publisher, 1995: 437-553.

70. Bovenzi M, Stanta G, Antiga G, Cavallieri F. Occupational exposure and lung cancer risk in a coastal area of northeastern Italy. Int Arch Occup Environ Health 1993;65:35-41.

71. de Klerk NH, Musk W, Eccles JL, Hansen J, Hobbs MST Exposure to crocidolite and the incidence of different histological types of lung cancer. Occup Environ Med 1996;53: $157-9$.

72. Barrett JC. Cellular and molecular mechanism of asbestos carcinogenicity: implications for biopersistence. Environ Health Perspect 1994;102:19 - 23 .

73. Mossman BT, Kessler JB, Ley BN, Craighead JE. Interaction of crocidolite asbestos with hamster respiratory mucosa in organ culture. Lab Invest 1977;36:131-9.

74. Heintz NH, Janssen YM, Mossman BT. Persistent induction of c-fos and c-jon expression by asbestos. Proc Natl Acad Sci USA 1993:90:3299-303.

75. Oberdöster G. Macrophage-associated responses to chrysotile. Ann Occup Hyg 1994;38:601-15.

76. Merler E, Brizzi S. Compensation of occupational diseases and particularly of asbestos-related diseases among European Community (EEC) countries. Epidemiol Prev 1994;18:170-9.

77. Rose G. The strategy of preventive medicine. Oxford: Oxford Medical Publications, 1992.

78. Seidman H, Selikoff IJ. Decline in death rates among asbestos insulation workers 1967-1986 associated with diminution of work exposure to asbestos. Ann NY Acad Sci 1989;300-18.

79. Walker AM. Declining relative risk for lung cancer after cessation of asbestos exposure. J Occup Med 1984;26:422-6.

80. Swerdlow AJ. Effectiveness of primary prevention of occupational exposures on cancer risk. In: Hakama M, Beral V, Cullen JW, Parkin DM, editors. Evaluating effectiveness of primary prevention of cancer. Lyon: International Agency for Research on Cancer (IARC), 1990. IARC scientific publications no 103:23-56.

81. Hakama M, Beral V, Cullen JW, Parkin DM, editors. Evaluating effectiveness of primary prevention of cancer. Lyon: International Agency for Research on Cancer (IARC), 1990. IARC scientific publications, no 103.

82. Kaldor J, Byar DP. Quantification of the effects of preventive measures. In: Hakama M, Beral V, Cullen JW, Parkin DM, editors. Evaluating effectiveness of primary prevention of cancer. Lyon: International Agency for Research on Cancer (IARC), 1990:13-22. IARC scientific publications, no 103.

83. Lubin JH, Blot WJ. Lung cancer and smoking cessation: patterns of risk. JNCI 1993;85:422-3.

84. Halpern MT, Gillespie BW, Warner KE. Patterns of absolute risk of lung cancer mortality in former smokers. JNCI 1993;85: $457-64$.

85. Tverdal A, Thelle D, Stensvold I, Leren P, Bjartveit K. Mortality in relation to smoking history: 13 years' follow-up of 68.000 Norwegian men and women aged $35-49$ years. J Clin Epidemiol 1993;45:475-87.

86. Doll R, Peto R, Wheatley K, Gray R, Sutherland I. Mortality in relation to smoking: 40 years' observations on male British doctors. BMJ 1994;309:901-11.

Received for publication: 28 October 1996 